\title{
MEETING CALENDAR
}

\section{May 1-5, 1996-Canadian Association of African Studies}

$\Delta$ Annual meeting of the Canadian Association of African Studies,in Montreal. Theme: "Africa 1996 Afrique: Crisis and Renaissance et Crise."Contact Loy Denis, CAAS Secretariat, Centre d'Etudes de l'Asie de l'Est, Universite de Montreal, C.P. 6128, Succ. Centre Ville, Montreal, Quebec H3C 3J7, Canada. Tel: (514) 343-6569, fax: (514) 343-7716, E-Mail: denm@ere.umontreal.ca.

\section{June 24-August 16, 1996-Social Science}

A Center for Afroamerican and African Studies of the University of Michigan-Ann Arbor 1996 Summer Institute on Social Science Methods and African Studies. Contact 1996 Summer Institute, Center for Afroamerican and African Studies, 200 West Engineering Building, University of Michigan, Ann Arbor, MI 48109-1092. Tel: (313) 764-5513, fax: (313) 763-0543, e-mail: caasinformation@umich.edu.

\section{September 3-6, 1996-Archaeology}

$\Delta$ 13th Biennial Conference of the Society of Africanist Archaeologists, in Poland. Themes: "The Archaeological Heritage of Africa: Management and Challenges," and "The Impact of Past Human Activities Upon Africa's Natural Environments." Contact Lech Krzyzaniak, Poznan Archaeological Museum, ul. Wodna 27, 61-781 Poznan, Poland. Tel: 48/61/52.64.30, fax: $48 / 61 / 52.53 .06$.

\section{October 30-November 2,} 1996-Ethnomusicology

$\Delta$ 41st Annual Meeting of the Society for Ethnomusicology. Joint meeting with the Canadian Society for Traditional Music. Contact Beverly Diamond, Music Department, York University, 4700 Keele St., North York, Ontario, Canada, M3J 1 P3. E-mail: bdiamond@yorku.ca

November 11-20, 1996-Power and Culture $\Delta$ Center for Afroamerican and African Studies of the University of Michigan-Ann Arbor 1996 International Workshop. Theme: "Transformations of Power and Culture in Africa." Contact 1996 International Workshop, Center for Afroamerican and African Studies, 200 West Engineering Building, University of Michigan, Ann Arbor, MI 48109-1092. Tel: (313) 764-5513, fax: (313) 763-0543, e-mail: caasinformation@umich.edu.
November 13-15, 1996-Land Tenure and Administration

A University of Florida (Gainesville) International Conference on Land Tenure and Administration. Contact: Grenville Barnes, Surveying and Mapping Program, Department of Civil Engineering, 345 Weil Hall, University of Florida, Gainesville, Florida, 32611. Tel: (352) 392-4998, fax: (352) 392-4957, e-mail: gbarn@ce.ufl.edu.

November 15-17, 1996-Religion and Art A International symposium on "Art and Rituals of Divination in Central and West Africa," hosted by the Department of Religion, Amherst College. Contact John Pemberton III, Department of Religion, Amherst College, Amherst, MA 01002. Tel: (413) 542-2211, fax: (413) 542-2727.

November 23-26, 1996-African Studies - 39th Annual Meeting of the African Studies Association, in San Francisco, CA. Theme: "The Challenges of Renewal in Africa." Contact the Secretariat, ASA, Emory University, Credit Union Building, Atlanta, GA 30322.

\section{January 2-5, 1997-History}

- Annual meeting of the American Historical Association, in New York City. Theme: "Human Rights." Contact Margaret Strobel, Women's Studies Program, Office of Social Science Research, B-110 BSB, 1007 W. Harrison, University of Illinois at Chicago, IL 60607-7136.

Mid-February, 1997-Images and Empire $\Delta$ Conference to be held at Yale University. Theme: "Images in Africa that Bear the Mark of Empire." Contact Paul S. Landau, Dep't of History, PO Box 208324, Yale University, New Haven, CT 06520. E-mail: plandau@minerva.cis.yale.edu.

\section{March 21-23, 1997-Theatre Studies}

A Conference sponsored jointly by the University of Bristol Drama Department and the Colston Research Society. Theme: "New Approaches to Theatre Studies and Performance Analysis." Contact Günther Berghaus, Department of Drama, University of Bristol, Cantocks Close, Woodland Road, Bristol, BS8 1UP, UK. Tel: 0117/928 78 33, fax: $\quad 0117 / 928 \quad 8251$ e-mail: mark.sinfield@bris.ac.uk.

\section{SUMMER RESEARCH}

Please remember when you move to send us your change of address notice at least six weeks in advance (email it if you wish to africa@emory.edu). When the Post Office cannot deliver one of your periodicals, they rip off the cover and discard the rest. The cover is then returned to the Secretariat and a postage due charge is levied. The same thing happens when you temporarily stop your mail. Every year the ASA pays out between $\$ 500$ and $\$ 1,000$ in postage due charges. Help us keep your costs down by redirecting your mail in a timely manner.

\section{EMPLOYMENT OPPORTUNITIES}

\begin{abstract}
African Studies Program Director
* Indiana University invites applications for the position of Director, African Studies Program, to begin August, 1996. Contact Ruth M. Stone, Chair, African Studies Search Committee, Indiana University, Woodburn Hall 221, Bloomington, IN 47405. Tel: (812) 855-6825/8284, fax: (812) 855-6734.
\end{abstract}

\section{African/African American Studies * The University of Arizona, African American Studies Program invites applications for the following positions, beginning August 1, 1996: \\ - Art Historian, African/Diaspora Art \\ - African American Studies-Religion \\ - African American Studies-Sociology}

Contact M. S. Omari, Director, African American Studies Program, University of Arizona, MLK Building 305, Tucson, AZ 85721-0067.

\section{Education Specialist}

* The University of Illinois at Urbana-Champaign seeks a Specialist in Education who will coordinate the Center for African Studies Outreach Program. Contact Center for African Studies, University of Illinois at Urbana-Champaign, 201 International Studies Building, $910 \mathrm{~S}$. Fifth Street, Champaign, IL 61820. Tel: (217) 333-6335, fax: (217) 244-2429.

\section{West Africa Regional Representative} * Lutheran World Relief seeks a Regional Representative for its West Africa office located in Niamey, Niger. Contact Ann Fries, Human Resources Manager, Lutheran World Relief, 390 Park Avenue South, New York, NY 10016. Fax: (212) 213-6081. Interviews will be conducted beginning May 1. 